\title{
Short term feeding responses to starvation in three species of small calanoid copepods
}

\author{
Peter Tiselius* \\ Kristineberg Marine Research Station, S-450 34 Fiskebäckskil, Sweden
}

\begin{abstract}
Three small, neritic copepods (Acartia tonsa, Acartia clausi, and Centropages hamatus) were exposed to short term ( 1 to $14 \mathrm{~h}$ ) periods without food and their clearance over $2 \mathrm{~h}$ was measured. Clearance rates in controls consisting of copepods continuously exposed to 3500 cells $\mathrm{ml}^{-1}$ of the diatom Thalassiosira weissflogii were $1.15 \mathrm{ml} \mathrm{\mu g}{ }^{1} \mathrm{dry} \mathrm{wt}^{-1}$ for $\mathrm{A}$. tonsa, 0.65 for A clausi and 0.35 for $C$. hamatus. When moved from filtered sea water to a suspension of $3500 \mathrm{~T}$ weissflogii $\mathrm{ml}^{-1}$. A. tonsa showed elevated (compared to controls) clearance rates after having been deprived of food for $6 \mathrm{~h}$ $(+77 \%)$ and $14 \mathrm{~h}(+44 \%)$. A. clausi only responded after $14 \mathrm{~h}$ of starvation $(+60 \%)$ whereas C. hamatus showed a moderate response after $6 \mathrm{~h}$ without food $(+14 \%)$. In day-night comparisons with $A$. tonsa, elevated clearance rates were significantly higher only dunng the day. Frequent estimates of clearance rates (20 min intervals) showed that the stimulating effect of food deprivation only lasted $\sim 1 \mathrm{~h}$ in the case of $1 \mathrm{~h}$ of starvation but lasted more than $3 \mathrm{~h}$ after $14 \mathrm{~h}$ without food. Small species like the ones investigated here have more restricted vertical migration and may not leave the food-rich surface layer to avoid predation, as is commonly found in larger copepods. Instead, they have to balance food intake with predator avoidance continuuusly. The hunger responses observed in the study may allow the copepods to intermittently search for food or avoid predators and still maintain the same overall ingestion rate as constantly feeding animals.
\end{abstract}

KEY WORDS: Acartia tonsa - Acartia clausi Centropages hamatus - Clearance rates - Hunger responses

\section{INTRODUCTION}

Intermittent feeding is a common feature in most calanoid copepods. Large taxa like Calanus show a strong diel signal in feeding (Landry \& Hassett 1985), digestion (Nott et al. 1985) and vertical position in the water column (reviewed by Haney 1988). There have been metabolic explanations for this (Enright 1977), but when tested experimentally evidence points to predator avoidance as the proximal cause (Lampert et al. 1988). Shorter term feeding periodicities are less well investigated and in particular the dynamics of ingestion and hunger in small copepods is largely unknown. These less migratory copepods may show feeding periodicity even when surrounded by food (e.g. Dagg \& Grill 1980, Stearns 1986, Durbin et al. 1990). Food resources are often patchy and swimming copepods experience a fluctuating environment where

•E-mail: p.tiselius@kmf.gu.se periods of hunger and satiation alternate. The feeding responses of small copepods to variable food conditions are the focus of this paper

What are the time scales of hunger responses for small copepods in patchy environments? Length of starvation periods depends on the patchiness of food and on the swimming capacity of the copepods. The shortest time scales correspond to the time it takes to fill or empty the gut, 15 to $45 \mathrm{~min}$ in the case of Acartia tonsa (Durbin et al. 1990). At the longest scale are starvation times of 3 to $6 \mathrm{~d}$, which are the limit for survival of small copepods (Dagg 1977, Parrish \& Wilson 1978). A. tonsa can recover from shorter starvation times: after 1 to $3 \mathrm{~d}$ without food $A$. tonsa requires 2 to $4 \mathrm{~d}$ in abundant food to regain full reproduction (Parrish \& Wilson 1978). Field-caught and starved A. tonsa attained normal weight within $24 \mathrm{~h}$ when fed ad libitum (Thompson et al. 1994). Starvation for more than $24 \mathrm{~h}$ will not be caused by patchy food resources and the failure of copepods to find patches. Rather, overall food 
limitation is likely in such cases, since even small copepods have the potential to search and find patches of food in the upper mixed layer in less than $24 \mathrm{~h}$. Behaviour and dynamics of feeding in response to patchiness of food would therefore operate on time scales of 1 to $24 \mathrm{~h}$ for small copepods.

Intermittent feeding may be caused by variable food supply, but will at some point also be constrained by digestive capabilities. The digestion process of calanoid copepods has been investigated with regard to enzyme production and secretion (e.g. Mayzaud \& Poulet 1978). Detailed investigations have been carried out for both Calanus helgolandicus (Nott et al. 1985, Hassett \& Landry 1983, 1988) and Acartia tonsa (Hassett \& Blades-Eckelbarger 1995). The digestion in these copepods is initiated by the release of enzymes from $B$ cells (blister cells) into the gut. In $C$. helgolandicus the $B$-cells are broken down within $7 \mathrm{~h}$ and new ones have to be formed before the digestion can proceed (Nott et al. 1985). Copepods may continue feeding after this time but the food does not appear to be digested. The activity and breakdown of $\mathrm{B}$-cells is synchronised with the feechiny in suriace iayers at night. C. helgolandicus undertakes extensive vertical migrations and encounters food only at night, which makes it unnecessary to have enzymes available in the day.

Acartia tonsa show a similar periodicity in feeding activity, but in contrast their B-cells exhibit continuous activity and formation (Hassett \& Blades-Eckelbarger 1995). The cells contain larger vacuoles at night, corresponding to a higher enzyme secretion, but digestive activity is maintained throughout the $24 \mathrm{~h}$. As for Calanus, the diel feeding activity in A. tonsa is proposed to be a response to increased predation risk during the day. But even though predator induced migrations occur in $A$. tonsa and A. hudsonica (e.g. Stearns 1986) and A. hudsonica (Bollens \& Frost 1989), they are less extensive and do not bring the copepods beyond the food-rich surface layer.

Starvation responses have been shown for both species as well. Calanus pacificus increase enzyme activity in response to longer times of starvation (12 d; Landry \& Hassett 1985) and can therefore reach a higher assimilation efficiency temporarily. Shorter starvation times ( 22 to $26 \mathrm{~h}$ ) induce 1 to 3 times higher clearance rates and a shift in retention efficiency, which points to an increased pumping rate (Runge 1980). C. pacificus starved for 1 to $3 \mathrm{~d}$ increased their feeding activity temporarily, but after $8 \mathrm{~h}$ most of this response had levelled off (Mackas \& Burns 1986). For Acartia tonsa, Thompson et al. (1994) found a 2 - to 3 -fold difference in maximum. ingestion caused by food limitation in the field at the time of capture. Recovery was, however, fast; in high food conditions the copepods had already recovered in terms of body weight and condition factor within $24 \mathrm{~h}$.
From the above it is clear that the small copepods have flexible and less synchronised behaviours that must operate on shorter time scales than in the case of diurnal migrators. The small species often dominate coastal zooplankton communities, yet an understanding of their responses to fluctuations in both food availability and predator fields is lacking.

In this study I investigated the short term (minutes to hours) feeding response of small copepods exposed to various degrees of starvation. The experimental design was similar to Hassett \& Landry (1988), but considerably shorter time scales were investigated. Three small neritic copepods. Acartia tonsa, A. clausi and Centropages hamatus, were starved for 1 to $14 \mathrm{~h}$ in filtered sea water and then allowed to feed in a dense suspension of the diatom Thalassiosira weissflogii. Their clearance rates were compared with those in continuously fed copepods. Frequent samples were takcn in order to follow the temporal evolution of clearance rates after transfer.

\section{MATERIALS AND METHODS}

Adult female Acartia tonsa used in the experiments were reared from eggs in $70 \mathrm{l}$ plastic carboys at $18^{\circ} \mathrm{C}$, at $30 \%$ and in a 12:12 h light:dark cycle. Each day a mixture of Rhodomonas baltica ( 6 to $7 \mu \mathrm{m}$ equivalent spherical diameter, ESD) and Thalassiosira weissflogii (10 to $12 \mu \mathrm{m} \mathrm{ESD}$ ) amounting to a volume concentration of 7 ppm ( $=40000$ cells $\mathrm{ml}^{-1}$ of $R$. baltica or 8000 cells $\mathrm{ml}^{-1}$ of $T$. weissflogii) was added to the carboys. Over $90 \%$ of this food addition was consumed within $24 \mathrm{~h}$. The cultured $A$. tonsa were used within 2 to $4 \mathrm{~d}$ after moulting to females, except in the experiments with longer starvation times ( 3 to $14 \mathrm{~h}$ ) where females within 3 wk after moulting were used (Table 1).

Female Acartia clausi and Centropages hamatus were collected close to the laboratory by towing a $200 \mu \mathrm{m}$ WP-2 net in the upper $5 \mathrm{~m}$ and diluting the catch in $10 \mathrm{l}$ buckets filled with surface water Fresh $A$. clausi and $C$. hamatus were collected for each experiment and within $3 \mathrm{~h}$ individually sorted into $200 \mathrm{ml}$ beakers at the laboratory.

The day before an experiment, copepods were transferred to $200 \mathrm{ml}$ beakers for acclimation. Fifty females were placed in each beaker and Thalassiosira weissflogii was added ad libitum (up to 9000 cells $\mathrm{ml}^{-1}$ but generally 2000 to 4000 cells $\mathrm{ml}^{-1}$ ). The concentration was maintained with a peristaltic pump or by manual additions of algae. Algal growth often balanced grazing, but concentrations were checked frequently with an Elzone $180 \mathrm{XY}$ electronic particle counter. In the experiments with longer starvation times ( 3 to $14 \mathrm{~h}$ ) with Arcartia tonsa, however, no separate overnight 
Table 1. Experimental conditions. For cultured copepods, age of females (days from moulting to female) is shown for field-caught copepods, date of collection is shown. Dry weight calculated from length-weight regressions [Acartia tonsa from Kiorboe et al. (1985) and A. clausi and Centropages hamatus from Klein Breteler et al. (1982)|. From 6 March to 16 April clearance rates were calculated from linear regressions and from 17 April to 23 July from formulae in Frost (1972)

\begin{tabular}{|c|c|c|c|c|c|c|}
\hline Species & Date & $\begin{array}{l}\text { Age }(\mathrm{d}) / \\
\text { collection } \\
\text { date }\end{array}$ & $\begin{array}{c}\text { Cephalothorax } \\
\text { length } \\
(\mathrm{mm} \pm \mathrm{SD})\end{array}$ & $\begin{array}{l}\text { Dry wt } \\
(\mu g)\end{array}$ & $\begin{array}{l}\text { Starvation } \\
\text { time } \\
\text { (h) }\end{array}$ & Time \\
\hline A. tonsa & $\begin{array}{l}6 \mathrm{Mar} \\
17 \mathrm{Mar} \\
18 \mathrm{Mar} \\
19 \mathrm{Mar} \\
16 \mathrm{Apr} \\
17 \mathrm{Apr} \\
17 \mathrm{Apr} \\
18 \mathrm{Apr} \\
18 \mathrm{Apr}\end{array}$ & $\begin{array}{r}9 \\
20 \\
21 \\
22 \\
1 \\
2 \\
2 \\
3 \\
3\end{array}$ & $\begin{array}{l}0.924 \pm 0.020 \\
0.924 \pm 0.020 \\
0.924 \pm 0.020 \\
0.924 \pm 0.020 \\
0.752 \pm 0.035 \\
0.752 \pm 0.035 \\
0.752 \pm 0.035 \\
0.752 \pm 0.035 \\
0.752 \pm 0.035\end{array}$ & $\begin{array}{c}10.4 \\
10.4 \\
10.4 \\
10.4 \\
5.65 \\
5.65 \\
5.65 \\
5.65 \\
5.65\end{array}$ & $\begin{array}{r}14 \\
6 \\
3 \\
1 \\
1 \\
1 \\
1 \\
1 \\
1\end{array}$ & $\begin{array}{l}\text { Day } \\
\text { Day } \\
\text { Day } \\
\text { Day } \\
\text { Day } \\
\text { Day } \\
\text { Night } \\
\text { Day } \\
\text { Night }\end{array}$ \\
\hline A. clausi & $\begin{array}{r}9 \mathrm{Jul} \\
17 \mathrm{Jul} \\
18 \mathrm{Jul} \\
23 \mathrm{Jul}\end{array}$ & $\begin{array}{l}7 \mathrm{Jul} \\
15 \mathrm{Jul} \\
16 \mathrm{Jul} \\
21 \mathrm{Jul}\end{array}$ & $\begin{array}{l}0.892 \pm 0.030 \\
0.919 \pm 0.030 \\
0.926 \pm 0.031 \\
0.908 \pm 0.024\end{array}$ & $\begin{array}{l}10.8 \\
12.1 \\
11.9 \\
11.4\end{array}$ & $\begin{array}{r}1 \\
3 \\
6 \\
14\end{array}$ & $\begin{array}{l}\text { Day } \\
\text { Day } \\
\text { Day } \\
\text { Day }\end{array}$ \\
\hline C. hamatus & $\begin{array}{l}9 \mathrm{Jul} \\
17 \mathrm{Jul} \\
18 \mathrm{Jul} \\
23 \mathrm{Jul}\end{array}$ & $\begin{array}{r}7 \text { Jul } \\
15 \text { Jul } \\
16 \text { Jul } \\
21 \text { Jul }\end{array}$ & $\begin{array}{r}1.02 \pm 0.048 \\
0.962 \pm 0.049 \\
0.988 \pm 0.048 \\
0.973 \pm 0.043\end{array}$ & $\begin{array}{l}18.6 \\
17.3 \\
16.1 \\
16.6\end{array}$ & $\begin{array}{r}1 \\
3 \\
6 \\
14\end{array}$ & $\begin{array}{l}\text { Day } \\
\text { Day } \\
\text { Day } \\
\text { Day }\end{array}$ \\
\hline
\end{tabular}

times at 20 min intervals; this procedure took a total of 90 min for all beakers. In the experiments with Acartia tonsa and longer starvation times ( 3 to $14 \mathrm{~h}$ ), only $1 \mathrm{ml}$ was withdrawn and then diluted 10 times before particle counting. This allowed longer experiments and was used to investigate starvation effects averaged over $3 \mathrm{~h}$ periods.

The bottles were kept standing on the laboratory bench at 18 to $20^{\circ} \mathrm{C}$ and in indirect natural daylight. Daytime experiments were run between 14:00 and 17:00 $\mathrm{h}$ and nighttime between 19:00 and 21:00 h. Nighttime experiments only included $1 \mathrm{~h}$ starvation and only Acartia tonsa. After the end of the experiment, females were checked for viability (mortcility $<4 \%$ ) and their cephalothorax lengths measured.

For Acartia tonsa, clearance rate (volume swept clear of algae) under various degrees of starvation was calculated as follows. In each experiment a linear regression was performed on acclimation was arranged and the copepods were just exposed to the rearing concentration.

At least 3 h prior to the starvation troatment, all experimental copepods received a suspension of Thalassiosira weissflogii that was identical to the experimental concentration (3000 to 4500 cells $\mathrm{ml}^{-1}$, but generally 3500 cells $\mathrm{ml}^{-1}$ ). During this time the copepods were counted and new ones added (never $>3$ ) to keep the abundance at 50 per beaker. After this short term acclimation the starvation treatment was started by rinsing the copepods into $200 \mathrm{ml}$ beakers with either filtered sea water or a fresh suspension of $T$. weissflogii. Starvation times ranged from 1 to $14 \mathrm{~h}$. After the starvation treatment copepods were rinsed into $100 \mathrm{ml}$ screw cap bottles filled with 3500 cells $\mathrm{ml}^{-1}$ of $T$. weissflogii. Two to three replicates were used and the treatments were:

(1) controls without copepods

(2) well fed copepods that had not been starved

(3) copepods starved for 1, 3, 6 or $14 \mathrm{~h}$.

Only 1 starvation period could be tested in each experiment; thus, testing the 4 starvation periods corresponded to 4 separate experiments on different dates (Table 1).

The water in the beakers was gently mixed with a small plunger and $9 \mathrm{ml}$ withdrawn with a pipette for counting. After sampling all the bottles the samples were counted on the particle counter and then the next round of samples were taken. Each beaker was sampled 4
In-transformed concentrations versus time. Then the difference between controls and experimental bottles was estimated by methods in Bailey (1981) for comparisons of regressions coefficients from 2 small samples with unknown variances not assumed to be equal. The difference, with its standard error, was used to calculate clearance rate. To test the difference between starved and well fed conditions, the slopes corresponding to the 2 conditions were tested with a t-test (Bailey 1981), i.e. the variance induced by variability in the controls was not included in this test.

For tests of day-night differences with Acartia tonsa, separate clearance calculations for each 20 min sampling interval with appropriate volumes were performed. At each interval clearance was estimated from the difference between $g$ and $k$ in Frost's formulae (Frost 1972). This method causes a high variability and the estimates will not be independent of each other since the ending concentration for one interval is used as the starting concentration for next. Despite these problems, the method made it possible to follow the dynamics of ingestion rates over a time interval comparable to gut filling time. To reduce variability, the growth coefficient was determined from linear regression of concentration over the entire experimental time in control bottles and hence did not change between time intervals. With this method a mean and standard error for 8 to 12 clearance estimations from each experiment are presented (concentrations measured 5 times, 2 to 3 replicates). Differences are compared by 1 -factor 
ANOVA for each experiment separately. In the experiments with field-caught $A$. clausi and Centropages hamatus clearance estimation followed this method.

Since the volume of experimental bottles was only $100 \mathrm{ml}$, each subsample taken without removing copepods will increase the apparent clearance rate when it is based on linear regression. Accordingly, clearance rates estimated from regressions were 7 to $13 \%$ higher than rates calculated from each separate sample interval (Fig. 1). Both rates were strongly correlated and the slope was not significantly different from 1 ( $t$-test, $t=-0.1007, \mathrm{df}=11$ ).

Acartia tonsa females from 2 generations with different size were used in the experiments and, to make a comparison between all experiments possible, the clearance rates were normalised to body weight (Table 1).

\section{RESULTS}

Both Acartia species increased their clearance rates when deprived of food for periods longer than $3 \mathrm{~h}$ (Figs. 2 \& 3). Acartia tonsa had the highest weight

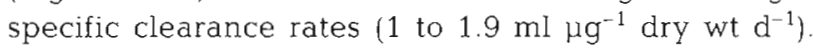
The increase was significant for both $6 \mathrm{~h}$ and $14 \mathrm{~h}$ starvation times ( $t$-test; $\mathrm{p}<0.002, t=4.073$, df $=13.3$ and $\mathrm{p}<0.001, t=5.23, \mathrm{df}=10.23$, respectively). A. clausi responded similarly but with only half the weight specific clearance rate $\left(0.5\right.$ to $1.2 \mathrm{ml}_{\mu \mathrm{g}^{-1}}$ dry wt $\left.\mathrm{d}^{-1}\right)$ and a significant increase only after 14 h starvation (1-factor ANOVA $_{i} \mathrm{p}=0.022$, df $=1,14, F=6.64$ ). Centropages hamatus had the lowest weight specific clearance rates

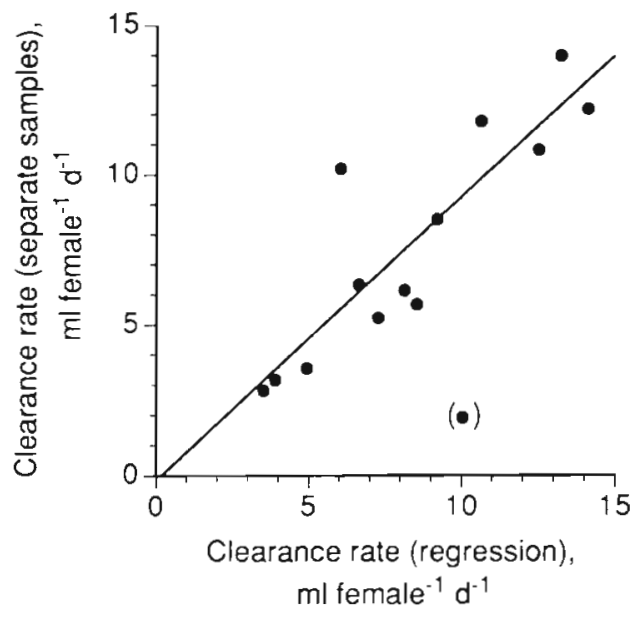

Fig. 1. Comparison of clearance rates calculated from linear regressions and from separate samples. Data for Acartia tonsa only. One point (within parentheses) is excluded from the regression due to highly variable clearance rate estimated from separate samples. The equation for the regression line is: $f(x)=0.94 x-0.17, R^{2}=0.76$

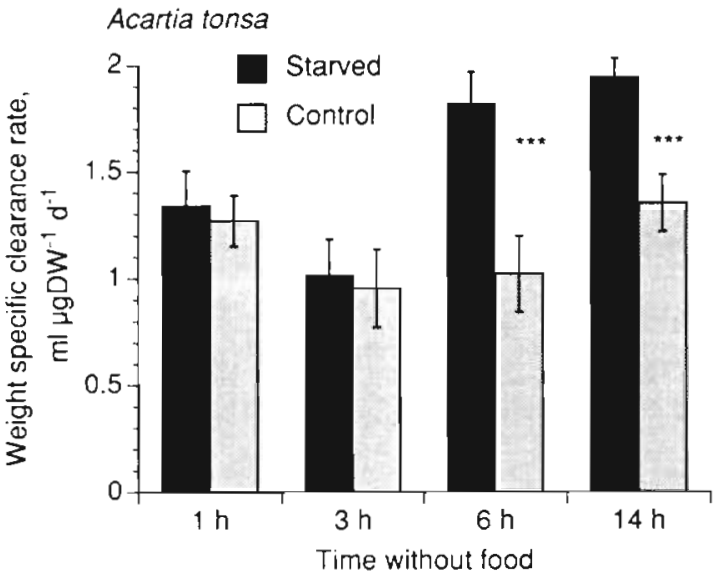

Fig. 2. Acartia tonsa. Effect of starvation time $(1,3,6$ and $14 \mathrm{~h})$ on weight specific clearance rates. Clearance rates are estimated from the slopes of linear regressions of In-transformed cuncenlialions versus time. Controi: continuousiy fed copepods. Error bars $=S E_{i} \cdots$ significant differences between treatments and controls $(p<0.001, t$-test for the slopes of the regression lines). Each pair of columns represents 1 experiment and the regressions are based on 6 to 10 measurements

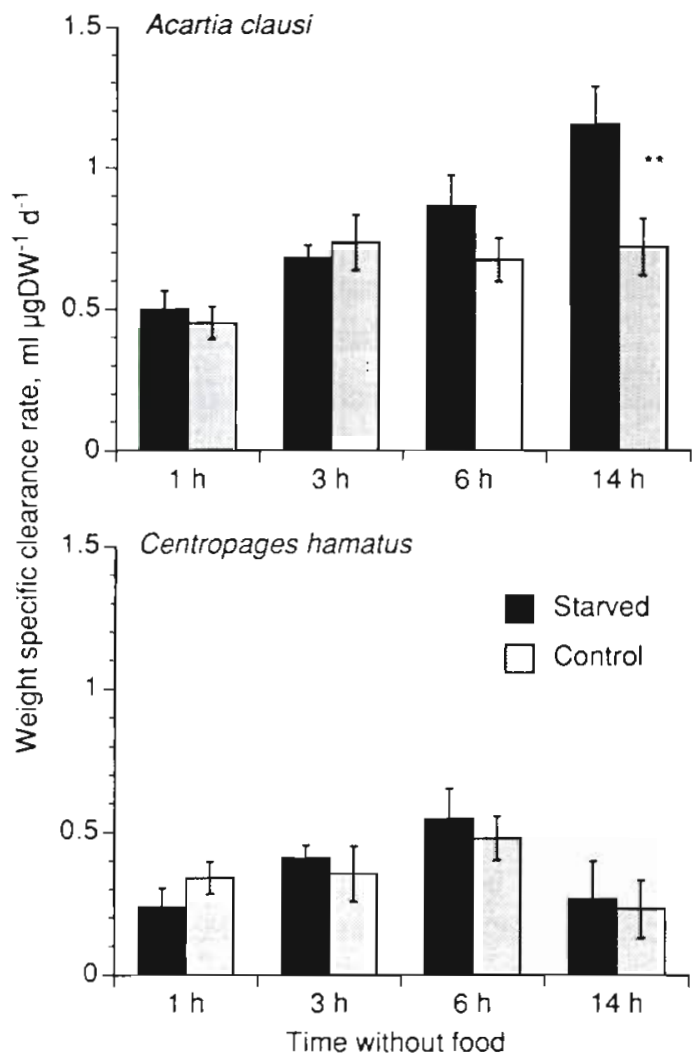

Fig. 3. Acartia clausi and Centropages hamatus. Effects of starvation tumes. Clearance rates are averages ( $n=8)$ of separate estimates for each 20 min time interval. Control: continuously fed copepods. "Significant difference between treatment and control ( 1 -factor ANOVA; $\mathrm{p}=0.022, \mathrm{df}=1,14$, $F=6.64)$. Error bars $=\mathrm{SE}$ 


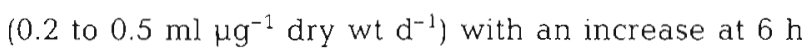
and no significant difference between controls and starvation treatments.

Two experiments were performed with Acartia tonsa to test day-night differences, each consisting of a series of measurements during the day and another at night (Fig. 4). There was no difference between clearance rates at night and during the day (2-factor ANOVA; $\mathrm{df}=1,60 \mathrm{j}$. Continuously fed copepods, however, had a significantly lower clearance rate than starved ones during the day (1-factor ANOVA; $p=0.025$, df $=1,30$, $F=5.53$ ). The daytime clearance rates in this series of experiments were lower than the corresponding $1 \mathrm{~h}$ starvation treatments presented above (Fig. 2) because females were considerably smaller (Table 1) and the normalisation to dry weight could not fully remove this size effect.

When the average clearance rates presented above are analysed in detail, it is apparent that the duration of increased clearance in the starvation treatment was quite brief (Fig. 5). In the case of Acartia tonsa, the analysis is based on the same data as in the day-night comparison above and one more experiment from day and night. There was a significant interaction between starvation time and sampling interval (2-factor ANOVA; $\mathrm{p}=0.0225, \mathrm{df}=3,96, F=3.34$ ). Starved copepods increased clearance to a maximum after $40 \mathrm{~min}$, then decreased again. Continuously fed copepods did not change clearance much after the initial determination. Significant differences were found in the 40 and 60 min sampling interval ( 1 -factor ANOVAs; $\mathrm{p}=0.0238$ and $0.0223, \mathrm{df}=1,24, F=5.83$ and 5.97, respectively), after which the effect of starvation disappeared. $A$. clausi already displayed a higher clearance rate in the first sampling interval, but only for the longest starva-

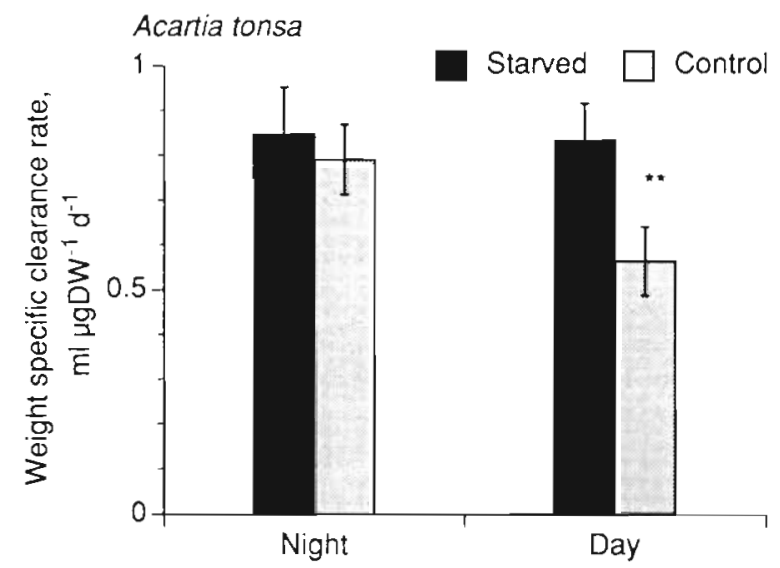

Fig. 4. Acartia tonsa. Effects of 1 h starvation time and time of the experiment (day or night) on weight specific clearance rates. Error bars $=S E, n=16$. Control: continuously fed copepods. "'Significant difference between treatment and control (1-factor ANOVA; $p=0.025, \mathrm{df}=1,30, F=5.53$ )

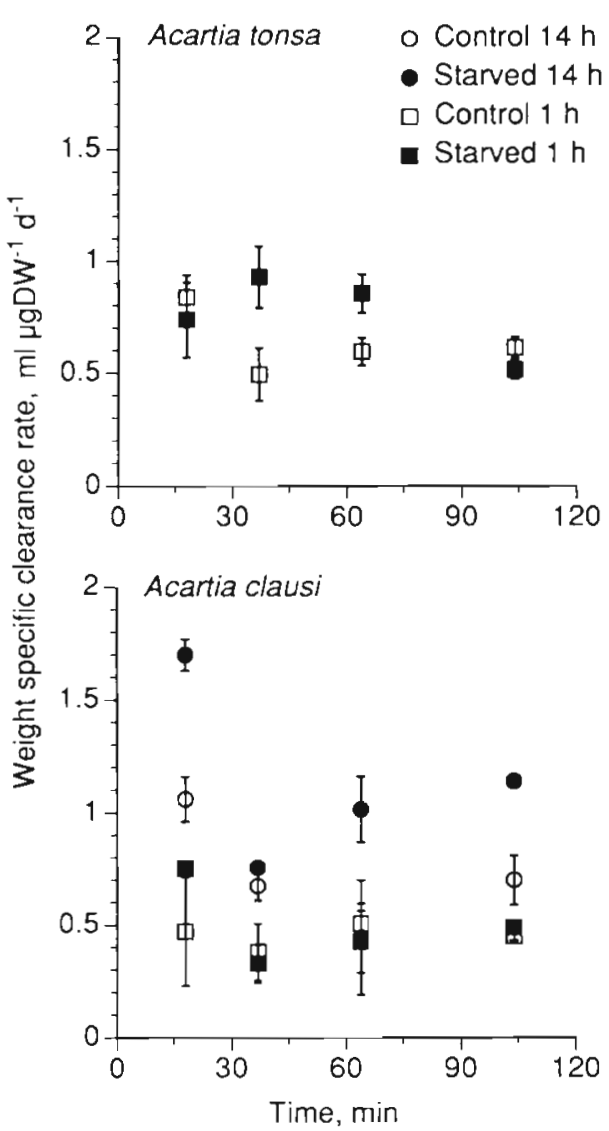

Fig. 5. Acartia clausi and A. tonsa. Transient responses over $2 \mathrm{~h}$ to starvation. Error bars $=\mathrm{SE}, \mathrm{n}=2$ (A. clausi) or $\mathrm{n}=13$ (A. tonsa). Control: continuously fed copepods. (Results for 14 h starvation are shown for $A$. clausi only)

tion time were both the sampling time and starvation effects significant ( 2 -factor ANOVA; $p=0.001, \mathrm{df}=1,8$, $F=25.2$ for starvation time and $\mathrm{p}=0.0019$, df $=3,8$, $F=13.0$ for sampling time). The increased clearance rate also lasted longer at the most severe starvation level, and even after 100 min there was a pronounced difference.

There was a general drop in clearance at 40 min and this may be due to the method for calculating separate clearance rates at each 20 min interval. The method tends to give alternating high and low rates, since a low start concentration (associated with high clearance rate in the preceding interval) will give a lower clearance in the next interval (see 'Materials and methods').

\section{DISCUSSION}

The copepods in the experiments were under very crowded conditions and this may affect the feeding behaviour negatively. Ingestion rate calculated from the average clearance rate in the controls with contin- 
uously feeding copepods was 41900 cells female ${ }^{-1} \mathrm{~d}^{-1}$ for Acartia tonsa (Fig. 2), which is comparable to the 38200 cells female ${ }^{-1} \mathrm{~d}^{-1}$ of the larger clone of Thalas siosira weissflogii reported by Thompson et al. (1994). $A$. clausi had a considerably lower average ingestion of 26300 cells female ${ }^{-1} \mathrm{~d}^{-1}$ or a clearance rate of $7.5 \mathrm{ml}$ female $e^{-1} \mathrm{~d}^{-1}$, which is lower than the 10 to $12 \mathrm{ml}$ female ${ }^{-1} \mathrm{~d}^{-1}$ reported by Saiz et al. (1992). Centropages hamatus had the lowest ingestion rate, 21000 cells female ${ }^{-1} d^{-1}$ in continuously feeding copepods. Van Alstyne (1986) found an ingestion of 36000 beads (10 to $40 \mu \mathrm{m}$ ) flavoured with $T$. weissflogii per female and day. Her treatment was similar to the $6 \mathrm{~h}$ starvation in this study where a comparable ingestion of 30800 cells female ${ }^{-1} \mathrm{~d}^{-1}$ was found. C. hamatus has a lower retention of small cells than Acartia, which explains the $\sim 50 \%$ lower weight-specific clearance rates (Tiselius 1989).

The difference between the 2 Acartia species is well documented and both have a higher daily ration (120 to $148 \%$ body carbon $\mathrm{d}^{-1}$; Durbin et al. 1990 ) than the 15 to $85 \%$ reported for Centropages hamatus (Kiørboe et al. 1982, Conley \& Turner 1985). Experimental copepods apparently showed signs of crowding stress but feeding rates were not unrealistic. The clearance rates should not be considered absolute but relative, i.e. as compared with the controls of continuously feeding copepods. The experimental food concentration was $31.5 \mu \mathrm{C} \mathrm{I}^{-1}$ assuming a carbon content of $90 \mathrm{pg} \mathrm{C}$ cell $^{-1}$ (Gismervik 1997), which is in the high end of natural concentrations (Kiørboe \& Nielsen 1994), but well within the range of peak concentrations found in patches (e.g. Bjørnsen \& Nielsen 1991). Summarising the methods used in the study, the experimental procedures were chosen to detect very short term effects $(<1 \mathrm{~h})$, which made it necessary to use a high copepod abundance. The copepod concentrations may yield lower than natural ingestion rates but the difference in food concentrations (filtered sea water vs $315 \mu \mathrm{g} \mathrm{Cl}^{-1}$ ) may invoke more extreme responses than in nature.

Two different responses to starvation were apparent in this study. The shortest effect was on the time scale of gut filling and was observed in most experiments irrespective of degree of starvation. During the first 40 to $60 \mathrm{~min}$, clearance rates were higher for Acartia tonsa that had been deprived of food even for as little as $1 \mathrm{~h}$. This corresponds to the starvation effect observed by Runge (1980) and Mackas \& Burns (1986) for Calanus pacificus in that it is a temporary effect decoupled from availability of enzymes or somatic changes due to starvation. The copepods apparently have an increased filtration rate during the time it takes to fill the gut. Since $A$. tonsa has an enzyme production that responds quickly to changes in food concentration (Hassett \& Blades-Eckelbarger 1995), there is no limiting factor other than gut volume for the intake. One hour of starvation is on the same time scale as gut clearance time at $20^{\circ} \mathrm{C}$ for A. hudsonica $(12$ to 15 min, $Q_{10}=1.88$; Wlodarczyk et al. 1992) and Centropages hamatus ( $32 \mathrm{~min}, Q_{10}=3.8$; Kiørboe et al. 1982) and accordingly occurred even after a short time without food. For Calanus helgolandicus that normally empties its entire enzyme pool daily (Nott et al 1985). the increase observed by Runge (1980) after 22 to $26 \mathrm{~h}$ starvation may be interpreted similarly. Calanus has a greater capacity to ingest more during a short time due to its larger gut, but also because it builds up a supply of enzymes that can be quickly secreted.

The effect of longer starvation times $(>6 \mathrm{~h})$ in this study was different from that of short term starvation. Average clearance rates measured over the length of an experiment $(90 \mathrm{~min})$ were significantly higher for the 2 Acartia species at the longest starvation times. This is in addition to the difference during the first 40 to $60 \mathrm{~min}$ and implies that, even after the gut was filled, there was a capacity for higher ingestion in starved copepods. An explanation may be found in the fact that Acartia can rapidly change its body weight in response to a changing food environment (Thompson et al. 1994). In experiments with $A$. tonsa average weight increased $25 \%$ over $24 \mathrm{~h}$ when copepods from the field were fed 2000 cells $\mathrm{ml}^{-1}$ of Thalassiosira weissflogii. The effect was dependent on the field condition factor but copepods had fully recovered from the food limited state within the $24 \mathrm{~h}$. In the present study the 2 Acartia species continued feeding at elevated rates when they had been starved more than $6 \mathrm{~h}$ ( $A$. tonsa) or $14 \mathrm{~h}$ ( $A$. clausi) even though their guts were filled. During this recovery time $A$. tonsa presumably allocate energy to somatic growth rather than to egg production (Thompson et al. 1994).

A persistent increase in ingestion rate may be explained by changed assimilation efficiency (AE). Landry et al. (1984) reported that Calanus pacificus acclimated to low food levels showed a higher AE than continuously feeding copepods. However, AE did not reach higher levels until 6 to $8 \mathrm{~h}$ after feeding had commenced following $2 \mathrm{~d}$ starvation (Hassett \& Landry 1988). The authors suggested that long lasting starvation may require the new formation of R-cells, cells responsible for uptake and storage, before assimilation can take place. The prolonged elevated ingestion after $14 \mathrm{~h}$ starvation in Acartia clausi in the present study may therefore be due to low AE, caused by lack of R-cells, and a concomitant decrease in gut passage time.

Centropages hamatus showed a maximal response after $6 \mathrm{~h}$ starvation but it was still less pronounced than for the Acartia species. Starvation for $14 \mathrm{~h}$ had severe effects and even feeding capacity was reduced. A 
congener, $C$. typicus, has been found to be more sensitive to starvation than $A$. tonsa (Dagg 1977) and $12 \mathrm{~h}$ starvation resulted in a $50 \%$ reduction in egg production. When the pulsing of food was more moderate 10.5 to $2.0 \mu \mathrm{g} \mathrm{chl} \mathrm{a} \mathrm{l}^{-1}$ ), however, it did not affect survival of C. typicus (Davis \& Alatalo 1992). C. hamatus has a maximum growth rate of 0.27 to $0.31 \mathrm{~d}^{-1}$ (Klein Breteler et al. 1982, Fryd et al. 1991) compared to $0.45 \mathrm{~d}^{-1}$ for A. tonsa (Berggreen et al. 1988), so we should expect a correspondingly lower clearance rate $(\sim 0.7$ to $1.2 \mathrm{ml}$ $\mu^{-1}$ dry wt $\mathrm{d}^{-1}$ ). Observed rates were, however, only half of that. Due to lower retention efficiency (Tiselius 1989), the 3500 cells $\mathrm{ml}^{-1}$ of the small clone of Thalassiosira weissflogii used here may not suffice to saturate C. hamatus as in the case of Acartia.

The results found for small copepads in this study have implications for their survival in the highly variable surface mixed layer of the ocean. The investigated species are constantly moving in and out of patches of food, do not migrate extensively and do not leave their food to hide from predators as Calanus do. Instead. predator avoidance has to be accomplished by their behaviour wherever they are. The behavioural traits should therefore be evaluated with respect to potential gains in survival and reproduction, not only through increased ingestion and growth, but through reduced predation risk as well.

Increased feeding activity at night has heen shown for Acartia tonsa under constant food conditions (e.g Stearns 1986, Durbin et al. 1990) and providing $A$. grani with abundant food at night gave higher egg production than the same amount of food given during the day (Calbet \& Alcaraz 1996). Centropages typicus reduced its feeding during the day to levels that decreased egg production, even though food levels were the same as at night (Dagg \& Grill 1980). These and other observations show that the selective pressure to avoid predation clearly is high and should affect the feeding behaviour (e.g Tiselius et al. 1993, 1997). Increased predation risk in a constant food environment should thus give a more pronounced difference in feeding activity between starved and well fed copepods. Accordingly, the difference between controls and starved copepods in the day-night experiment (Fig. 4) suggests that well fed copepods suppressed their feeding activity when they might expect a higher predation risk, but that the hunger response overrode the predation risk during the day.

Short term increases of up to $70 \%$ (for $<1$ h) and sustained increases of $30 \%$ (for several hours) in clearance rate after starvation times of 6 to $14 \mathrm{~h}$ were found for the 2 Acartia species in this study. This should be compared to the patchiness of food resources experienced by small copepods in the sea. In extreme situations with strong-pycnocline-associated patches (e.g.
Bjornsen \& Nielsen 1991) the range of food concentrations used in this study may be realistic 0 to 3500 Thalassiosira weissflogii $\mathrm{ml}^{-1}$ ). But more often, as pointed out by Davis \& Alatalo (1992) and Calbet \& Alcaraz (1996), the gradients are less strong. Then the responses in small copepods will be weaker and probably unimportant for the daily food intake for any single copepod.

Short term intense feeding may still be advantageous if patches are formed and grazed down on a time scale of hours. The short term stimulation of clearance observed in this study already occurred after $1 \mathrm{~h}$ without food, that is, slightly longer than it takes to empty the gut. The potential to feed at higher rates temporarily may provide a window of opportunity for avoiding predators or finding new patches of food while keeping the same average ingestion rate as a hypothetical continuously feeding copepod. In the common situation of food limitation (e.g Kiørboe \& Nielsen 1994, Thompson et al. 1994), competition for food would also favour species that can ingest and assimilate more food per unit time. To evaluate this effect requires better knowledge of persistence of food patches in the sea and the copepods' in situ responses to them

Acknowledgements. I gratefully acknowledge the assistance of Kajsa Tönnesson and the staff at Kristineberg Marine Research Station. Stcve nnott and 3 anonymous reviewers gave valuable comments on the manuscript and financial support was provided by the Swedish Natural Sciences Research Council, grant B-AA/BU 09889.

\section{LITERATURE CITED}

Bailey (1981) Statistical methods in biology, 2nd edn. Hodder and Stoughton, London

Berggreen U, Hansen B, Kiørboe T (1988) Food size spectra, ingestion and growth of the copepod Acartia tonsa during development: implications for the determination of copepod production. Mar Biol 99:341-352

Bjornsen PK. Nielsen TG (1991) Decimeter scale heterogeneity in the plankton during a pycnocline bloom of Gyrodinuum aureolum. Mar Ecol Prog Ser 73:263-267

Bollens SM, Frost BW (1989) Predator-induced diel vertica] migration in a planktonic copepod. J Plankton Res 11 : $1047-1065$

Calbet A, Alcaraz M (1996) Effects of constant and fluctuating food supply on egg production rates of Acartia grani (Copepoda: Calanoida). Mar Ecol Prog Ser 140:33-39

Conley WJ, Turner JT (1985) Omnivory by the coastal marine copepods Centropages hamatus and Labidocera aestiva. Mar Ecol Prog Ser 21:113-120

Dagg MJ (1977) Some effects of patchy food environments on copepods. Limnal Oceanogr 22:99-107

Dagg MJ, Grill DW (1980) Natural feeding rates of Centropages typicus females in the New York Bight. Limnol Oceanogr 25:597-609

Davis CS, Alatalo P (1992) Effects of constant and intermittent food supply on life-history parameters in a marine copepod. Limnol Oceanogr 37:1618-1639 
Durbin AG, Durbin EG, Wlodarczyk E (1990) Diel feeding behavior in the marine copepod Acartia tonsa in relation to food availability. Mar Ecol Prog Ser 68:23-45

Enright JT (1977) Diurnal vertical migration: adaptive significance and timing. Part 1 . Selective advantage: a metabolic model. Limnol Oceanogr 22:856-872

Frost BW (1972) Effects of size and concentration of food particles on the feeding behavior of the marine planktonic copepod Calanus pacificus. Limnol Oceanogr 17(6): $805-815$

Fryd M, Haslund OH, Wohlgemuth O (1991) Development, growth and egg production of the two copepods species Centropages hamatus and Centropages typicus in the laboratory. J Plankton Res 13:683-689

Gismervik (1997) Copepod stoichiometry and predation on protozoa as structuring factors in marine pelagic food webs. PhD dissertation, University of Oslo

Haney JF (1988) Diel patterns of zooplankton behavior Bull Mar Sci 43:583-603

Hassett RP, Blades-Eckelbarger P (1995) Diel changes in gutcell morphology and digestive activity of the marine copepod Acartia tonsa. Mar Binl 124.59-69

Hassett RP, Landry MR (1983) Effects of food-level acclimation on digestive enzyme activities and feeding behavior of Calanus pacificus. Mar Biol 75:47-55

Hassett RP, Landry MR (1988) Short-term changes in feeding and digestion by the copepod Calanus parifirms. Mar Rinl 99:63-74

Kiorboe T, Mohlenberg F, Hamburger K (1985) Bioenergetics of the planktonic copepod Acartia tonsa: relation between feeding, egg production and respiration, and composition of specific dynamic action. Mar Ecol Prog Ser 26:85-97

Kiørboe T, Møhlenberg F, Nicolajsen H (1982) Ingestion rate and gut clearance in the planktonic copepod Centropages hamatus (Lil.jeborg) in relation to food concentration and temperature. Ophelia 21:181-194

Kiørboe T, Nielsen TG (1994) Regulation of zooplankton biomass and production in a temperate coastal ecosystem. 1 Copepods. Limnol Oceanogr 39:493-507

Klein Breteler WCM, Fransz HG, Gonzalez SR (1982) Growth and development of four calanoid copepod species under experimental and natural conditions. Neth J Sea Res 6: $195-207$

Lampert W, Schmitt RD, Muck P (1988) Vertical migration of freshwater zooplankton: test of some hypotheses predicting a metabolic advantage. Bull Mar Sci 43:620-640

Landry MR, Hassett PR (1985) Time scales in behavioral, biochemical, and energetic adaptations to food-limiting conditions by a marine copepod. Arch Hydrobiol (Beih) Ergebn Limnol 21:209-221

Editorial responsibility: Otto Kinne (Editor), Oldendorf/Luhe, Germany
Landry MR, Hassett RP, Fagerness V, Downs J, Lorenzen CJ (1984) Effect of food acclimation on assimilation efficiency of Calanus pacificus. Limnol Oceanogr 29(2):361-364

Mackas DL, Burns KE (1986) Poststarvation feeding and swimming activity in Calanus pacificus and Metridia pacifica. Limnol Oceanogr 31(2):383-392

Mayzaud P, Poulet SA (1978) The importance of the time factor in the response of zooplankton to varying concentrations of naturally occurring particulate matter. Limnol Oceanogr 23:1144-1154

Nott JA, Corner EDS, Mavin LJ, O'Hara SCM (1985) Cyclical contributions of the digestive epithelium to faecal pellet formation by the copepod Calanus helgolandicus. Mar Biol 89:271-279

Parrish KK, Wilson DF (1978) Fecundity studies on Acartia tonsa (Copepoda: Calanoida) in standardized culture. Mar Biol 46:65-81

Runge JA (1980) Effects of hunger and season on the feeding behavior of Calanus pacificus. Limnol Oceanogr 25: $134-145$

Saiz E, Alcaraz M, Paffenhöfer GA (1992) Effects of smallscale turbulcnce on feeding rate and gross-growth efficiency of three Acartia species (Copepoda: Calanoida). J Plankton Res 14:1085-1097

Stearns DE (1986) Copepod grazing behavior in simulated natural light and its relation to nocturnal feeding. Mar Ecol Prog Ser 30:65-76

Thompson AM, Durbin EG, Durbin AG (1994) Seasonal changes in maximum ingestion rate of Acartia tonsa in Narragansett Bay, Rhode Island, USA. Mar Ecol Prog Ser 10891-105

Tiselius P (1989) Contribution of aloricate ciliates to the diet of Acartia clausi and Centropages hamatus in coastal waters. Mar Ecol Prog Ser 56:49-56

Tiselius P, Jonsson PR, Kaartvedt $\mathrm{S}$, Olsen EM, Jørstad $\mathrm{T}$ (1997) Effects of copepod foraging behavior on predation risk: an experimental study of the predatory copepod Pareuchaeta norvegica feeding on Acartia clausi and $A$. tonsa (Copepoda). Limnol Oceanogr 42:164-170

Tiselius P, Jonsson PR, Verity PG (1993) A model evaluation of the impact of food patchiness on foraging strategy and predation risk in zooplankton. Bull Mar Sci 53: $247-264$

Van Alstyne KL (1986) Effects of phytoplankton taste and smell on feeding behavior of the copepod Centropages hamatus. Mar Ecol Prog Ser 34:187-190

Wlodarczyk E, Durbin AG, Durbin EG (1992) Effect of temperature on lower feeding thresholds, qut evacuation rate, and diel feeding behavior in the copepod Acartia hudsonica. Mar Ecol Prog Ser 85:93-106

Submitted: February 2, 1998; Accepted: April 30, 1998 Proofs received from author(s): June 8, 1998 